Berkala Ilmu Perpustakaan dan Informasi, Vol. 13, No. 1, Juni 2017, Hal. 79-86 DOI: http:// 10.22146/bip.26074

ISSN 1693-7740 (Print), ISSN 2477-0361 (Online)

Tersedia online di https://jurnal.ugm.ac.id/bip

\title{
KECENDERUNGAN SIVITAS AKADEMIKA DALAM MEMILIH SUMBER REFERENSI UNTUK PENYUSUNAN KARYA TULIS ILMIAH DI PERGURUAN TINGGI
}

\author{
Wahyu Supriyanto ${ }^{1}$, Rini Iswandiri ${ }^{1}$ \\ ${ }^{1}$ Pustakawan Universitas Gadjah Mada \\ e-mail:wahyus@ugm.ac.id
}

Naskah diterima: 18 Oktober 2016, direvisi: 10 Mei 2017 disetujui: 12 Juni 2017

Perpustakaan banyak menyimpan sumber-sumber referensi. Perpustakaan menjadi salah satu tempat untuk mengkaji ilmu pengetahuan. Perpustakaan UGM memiliki data pustaka meliputi buku cetak, buku elektronik, jurnal cetak, jurnal online, karya tulis ilmiah dosen repository. Pengguna perpustakaan adalah civitas akademika Universitas Gadjah Mada yang mencari referensi guna membuat karya tulis ilmiah. Penelitian ini bertujuan untuk mengetahui tingkat kunjungan pengguna perpustakaan dalam satu minggu dan mengetahui kecenderungan sivitas akademika mencari sumber referensi dalam pembuatan karya tulis ilmiah. Penelitian ini menggunakan metode deskriptif kuantitatif dengan menggunakan sampel 982 berdasarkan rumus Slovin. Hasil penelitian menunjukkan bahwa 1). Sivitas akademika sering melakukan kunjungan perpustakaan baik fisik maupun virtual sebesar 53\%. dengan intensitas kunjungan 1-2 kali dalam seminggu 2). Sivitas akademika UGM yang terbagi dalam 4 klaster (klaster Agrokomplek, klaster Kesehatan, Klaster Saintek, Klaster Sosio Humaniora) menunjukkan bahwa jurnal online menjadi rujukan terbanyak sebagai sumber referensi ilmiah sebesar $22.65 \%$.

Kata kunci: Perpustakaan UGM, sivitas akademika, intensitas kunjungan, referensi

\section{ABSTRACT}

Library became one of the places to study science with various resoruces. UGM Library provides printed and electronic books, printed and online journals, institutional repository. The library users cometo fins references for their scientific papers. This study aims to determine the level of user visits in the library in one week and understand the types of library resources they used. This research used quantitative descriptive approachwith 982 samples based on Slovin formula. The results showed that; 1). Academics often visited both physical and virtual library by 53\% with the intensity of visits 1-2 times a week 2). UGM academic community were divided into 4 groups (Agrokomplek, Health, Saintek, Socio Humanities) and used online journals as a reference by $22.65 \%$.

Keywords: library, academic community, visit intensity, reference

\section{A. PENDAhuluan}

Salah satu sarana penunjang program Tri Dharma Perguruan Tinggi adalah perpustakaan. Perpustakaan berkewajiban melaksanakan tugas dalam memilih, menghimpun, mengolah, merawat, serta melayankan sumber informasi kepada lembaga induk dan sivitas akademika di lingkungannya.

Kebutuhan informasi dosen dan mahasiswa wajib dipenuhi oleh perpustakaan, dengan menyediakan bahan pustaka rujukan pada semua jenjang akademis, ruang belajar, jasa peminjaman serta penyediaan jasa informasi aktif bagi pengguna (Septiyantono dan Sidiq, 2003). Berhasil dan tidaknya perpustakaan dalam mendukung proses pembelajaran di lingkungannya ditentukan oleh ketersediaan sumber informasi yang dimiliki. Besar kecilnya potensi sumber informasi di perpustakaan dalam pemenuhan kebutuhan pemustaka mampu membangun persepsi pemustaka terhadap perpustakaan. Sumber informasi di perpustakaan yang berpotensi lebih tinggi dalam pemenuhan kebutuhan pemustaka, akan dipersepsikan baik oleh 
pengguna. Sebaliknya, apabila sumber informasi hanya berpotensi rendah dalam pemenuhan kebutuhan pemustaka berakibat pada persepsi yang tidak baik terhadap perpustakaan (Munir, 2006). Dengan demikian penyediaan sumber informasi di perpustakaan yang berpotensi tinggi dalam mendukung kebutuhan pemustaka dapat dipergunakan sebagai indikator evaluasi sebuah perpustakaan.

Salah satu keberhasilan layanan perpustakaan yang berkualitas dapat diketahui dari persepsi pemustaka. Mereka akan memiliki persepsi yang baik terhadap perpustakaan, jika kebutuhannya terpenuhi. Sebaliknya, pemustaka akan memiliki persepsi buruk jika perpustakaan dianggap tidak mampu menyediakan dan memberikan layanan sesuai dengan kebutuhan pemustaka. Pelayanan prima dan profesional menjadi standar baku yang wajib dijalankan oleh pustakawan. Oleh karena itu, fungsi dan peran pustakawan sangat penting untuk menjaga kepuasan pemustaka. Nilai tambah lain dengan menerapkan standar pelayanan secara prima akan menaikkan citra positif ataupun image bagi perpustakaan. Layanan yang baik dapat dinilai dengan pengukuran 5 (lima) dimensi kualitas jasa menurut Parasuraman, Zeithaml, dan Berry (1985) yaitu meliputi daya tanggap (responsiveness), keandalan (reliability), jaminan (assurance), perhatian (emphaty) dan bukti fisik (tangible).

Perpustakan sebagai jantung universitas yang menempatkan perpustakaan sebagai pusat ilmu pengetahuan yang menyajikan koleksi buku, ejurnal, referensi, hasil-hasil penelitian, dan lainnya. Koleksi tersebut dapat digunakan oleh sivitas akademika sebagai bahan referensi untuk menyusun karya tulis ilmiah. Perpustakaan UGM merupakan salah satu perpusatakaan yang menyediakan koleksi (buku, e-jurnal, hasil-hasil penelitian) yang lengkap dan didukung fasilitas teknologi informasi yang memadai. Perpustakaan UGM memiliki beberapa koleksi seperti jurnal elektronik, buku teks, karya tulis ilmiah dosen, repository, buku elektronik dan jurnal cetak. Dana yang dialokasikan oleh Universitas Gadjah Mada mencapai 12 milyar dalam usaha melengkapi kebutuhan civitas akademika dalam hal sumber-sumber informasi. Untuk itu dibutuhkan penelitian lebih lanjut mengenai kecenderungan sivitas akademika dalam memilih sumber referensi untuk menyusun karya tulis ilmiah Hal ini bertujuan untuk meningkatkan jumlah sumber referensi yang sesuai dengan jumlah kebutuhan civitas akademika.
Buku pedoman KKN-PPM UGM menyebutkan bahwa UGM mempunyai empat klaster keilmuan, yaitu klaster Sains-Teknologi (Geografi, MIPA, Biologi, Teknik), SosioHumaniora (Ekonomi, Filsafat, Hukum, Ilmu Budaya, ISIPOL, Psikologi), KesehatanKedokteran (Farmasi, Kedokteran, Kedokteran Gigi) dan Agro (Kedokteran Hewan, Kehutanan, Pertanian, Peternakan, Teknologi Pertanian). Keempat klaster tersebut membutuhkan sumber referensi yang berbeda beda. Penelitian ini diharapkan dapat mengetahui kecenderungan sivitas akademika terutama mahasiswa tiap klaster dalam mengakses sumber daya informasi di Perpustakaan UGM. Hasil penelitian akan menjadi tolok ukur peningkatan sumber daya informasi dimasa yang akan datang. Selain itu, penelitian ini dilakukan untuk mengetahui kontribusi Perpustakaan UGM sebagai penyedia literatur untuk penyusunan karya tulis ilmiah bagi sivitas akademika.

Perpustakaan UGM diharapkan melakukan kajian secara berkala untuk mengetahui kebutuhan sumber informasi sivitas akademika sehingga pemustaka merasa puas dalam memanfaatkan perpustakaan.

\section{B. TINJAUAN PUSTAKA \\ a. Jenis Informasi}

Koleksi informasi di perpustakaan universitas biasanya berbentuk buku, literature book, majalah, jurnal, paper, dan lainnya akan semakin lengkap dengan koleksi-koleksi digital yang bisa berbentuk laporan laboratorium, laporan teknis data-data penelitian, dokumentasi penelitian, dan hasil-hasil penelitian. Hal ini terjadi karena penelitian bukan lagi tersimpan di database lembagan penelitian yang bersifat rahasia, tetapi sudah menjadi data publik yang memungkinkan pihak lain untuk berbagi data, membuat penelitian yang lebih baik, kolaborasi penelitian dan peningkatan reputes penelitian melalui publikasi yang professional (Cohen et.al., 2006).

Jenis kebutuhan informasi pengguna sangat beraneka ragam. Berhubungan dengan tugas pekerjaan, Jarverlin yang dikutip oleh Ishak (2003:4), memberi klasifikasi terhadap jenis kebutuhan informasi, yaitu:

1. Informasi yang berkaitan dengan masalah, menggambarkan struktur, sifat dan syarat dari masalah yang sedang dihadapi, misalnya dalam masalah konstruksi jembatan, informasi yang dibutuhkan adalah mengenal jenis, tujuan dan 
masalah yang dihadapi dalam membangun, konstruksi jembatan. Pada kasus ini kemungkinan telah ada sumber informasi yang telah membahas hal yang sama.

2. Informasi yang berkaitan dengan wilayah, terdiri dari pengetahuan tentang fakta, konsep, hukum dan teori dari wilayah permasalahan. Contohnya dalam masalah konstruksi jembatan, wilayah informasi yang diperlukan adalah kekuatan dan tingkat pemuaian besi. Jenis ini yang dibutuhkan berupa uji ilmiah dan teknologi informasi. Informasi yang dicari tersebut dapat ditemukan dalam terbitan jurnal ilmiah dan buku teks.

3. Informasi sebagai pemecahan masalah, menggambarkan bagaimana melihat dan memformulasikan masalah, apa masalah dan wilayah informasi bagaimana yang akan digunakan dalam upaya memecahkan masalah.

Sedangkan menurut Devadason yang dikutip oleh Ishak (2006:92) Jenis kebutuhan informasi tergantung pada kegiatan kerja, disiplin ilmu/ bidang pekerjaan/ minat, fasilitas yang tersedia, kedudukan atau jabatan seseorang, motivasi, kebutuhan untuk mengambil keputusan, kebutuhan untuk menemukan ide baru dan kebutuhan mencari kebenaran.

Dari uraian di atas dapat disimpulkan bahwa jenis kebutuhan informasi ada beberapa antara lain informasi yang berkaitan dengan masalah, informasi yang berkaitan dengan wilayah, informasi sebagai pemecahan masalah, dan jenis kebutuhan informasi tergantung pada kegiatan kerja, disiplin ilmu dan lain sebagainya.

\section{b. Pemanfaatan Koleksi Perpustakaan}

Untuk mengetahui apa yang dimaksud dengan pemanfaatan koleksi perpustakaan, maka terlebih dahulu harus diketahui defenisi dari pemanfaatan. Dalam Kamus Besar Bahasa Indonesia (2003:711), "Pemanfaatan mengandung arti proses, cara dan perbuatan memanfaatkan sesuatu untuk kepentingan sendiri”. Dari pengertian di atas dapat dirumuskan bahwa pemanfaatan koleksi perpustakaan adalah suatu proses yang dilakukan oleh pengguna dalam memanfaatkan informasi yang terdapat pada koleksi perpustakaan untuk memenuhi kebutuhan informasinya. Menurut Handoko yang dikutip oleh Handayani (2007:28), menyatakan bahwa dari segi pengguna pemanfaatan koleksi perpustakaan dipengaruhi oleh beberapa faktor yaitu:
Pertama, Faktor internal yang meliputi: Kebutuhan, yang dimaksud kebutuhan disini adalah kebutuhan informasi; Motif, merupakan sesuatu yang melingkupi semua penggerak, alasan atau dorongan yang menyebabkan ia berbuat sesuatu; Minat, adalah kecenderungan hati yang tinggi terhadap sesuatu.

Kedua, Faktor eksternal yang meliputi: Kelengkapan koleksi, yaitu banyaknya koleksi yang dapat dimanfaatkan informasinya oleh mahasiswa; Keterampilan pustakawan dalam melayani pengguna, yaitu keterampilan pustakawan dalam melayani mahasiswa dapat dilihat melalui kecepatan dan ketepatan mereka memberikan layanan; Keterbatasan fasilitas dalam pencarian kembali.

Perpustakaan perguruan tinggi sebaiknya memiliki ketersediaan koleksi yang banyak sesuai dengan kebutuhan informasi pengguna. Informasi atau dokumen yang tersedia sesuai dengan kebutuhan pengguna dikenal dengan istilah relevansi. Relevansi merupakan nilai antar koleksi dengan pengguna yaitu ukuran ketepatan suatu temu balik informasi antara koleksi yang dibutuhkan dengan pengguna yang membutuhkan informasi. Jadi ketersediaan koleksi pada perpustakaan harus mempunyai nilai relevansinya yaitu suatu nilai yang diberlakukan pada koleksi perpustakaan untuk dapat dimanfaatkan oleh seluruh pengguna perpustakaan yang dibutuhkan. Menurut Pao (1989: 54), "suatu transaksi temu balik dianggap sukses jika dokumen yang diperoleh relevan dengan kebutuhan pengguna yang memintanya. Relevansi dapat dijadikan criteria keberhasilan suatu temu balik informasi yang terdapat pada koleksi perpustakaan. Relevansi adalah suatu ukuran keefektivitasan antara sumber informasi dan penerima informasi”. Sedangkan menurut Pedoman Umum Perpustakaan Perguruan Tinggi (1982: 1), "koleksi perpustakaan hendaknya relevan dengan program pendidikan, pengajaran, penelitian dan pengabdian masyarakat yang diselenggarakan oleh lembaga induknya. Untuk ini perlu diperhatikan jenis, variasi dan jenjang program yang ada yaitu jumlah dan besar fakultas, jurusan, lembaga, departemen, dan seterusnya; tingkat diploma, sarjana, pasca sarjana dan doktor.

Berdasarkan pendapat di atas dapat disimpulkan bahwa relevansi merupakan nilai antara koleksi dengan pemustaka yaitu ukuran ketepatan suatu temu kembali informasi antara koleksi yang dibutuhkan dengan pemustaka yang membutuhkan literatur. Jadi ketersediaan literatur pada 
perpustakaan harus mempunyai nilai relevansinya yaitu suatu nilai yang diberlakukan pada literatur perpustakaan untuk dapat dimanfaatkan oleh seluruh pemustaka perpustakaan yang membutuhkan.

\section{METODE PENELITIAN}

Penelitian ini menggunakan metode kuantitatif. Menurut Uma Sekaran (2007:315) "penelitian cross sectional adalah penelitian dimana data dikumpulkan hanya sekali (yang dilakukan selama periode hari, minggu atau bulan). Untuk menjawab pertanyaan". Cross sectional method adalah metode peneltian yang mempelajari objek dalam kurun waktu tertentu.

Dalam penelitian ini, akan diukur pula tingkat kunjungan pemustaka. Tingkat kunjungan dapat dilihat dari berapa kali pemustaka mengunjungi perpustakaan dalam satu minggu. Pengambilan satuan ukuran minggu untuk kunjungan ke perpustakaan menjadikan responden dengan mudah menentukan tingkat kunjungannya.

- Populasi yaitu mengambil data dari civitas akademika UGM, Survei ini menggunakan Metode Multistage Random Sampling (Teknik penarikan acak bertingkat) berbasis Cluster, dengan menggunakan sampel sebanyak 982 responden yang terdiri terdiri dari 4 klaster yaitu:

\begin{tabular}{|c|c|c|c|}
\hline $\begin{array}{l}\text { Klaster } \\
\text { Saintek }\end{array}$ & $\begin{array}{c}\text { Klaster } \\
\text { Kesehatan }\end{array}$ & $\begin{array}{c}\text { Klaster } \\
\text { Agro }\end{array}$ & $\begin{array}{c}\text { Klaster } \\
\text { Sosio } \\
\text { Humaniora }\end{array}$ \\
\hline $\begin{array}{l}\text { Fakultas } \\
\text { MIPA } \\
\text { Fakultas } \\
\text { Geografi } \\
\text { Fakultas } \\
\text { Teknik } \\
\text { Fakultas } \\
\text { Biologi }\end{array}$ & $\begin{array}{l}\text { Fakultas } \\
\text { Kedokteran } \\
\text { Umum } \\
\text { Fakultas } \\
\text { Kedokteran } \\
\text { Gigi } \\
\text { Fakultas } \\
\text { Farmasi }\end{array}$ & $\begin{array}{l}\text { Fakultas } \\
\text { Kedokteran } \\
\text { Hewan } \\
\text { Fakultas } \\
\text { Kehutanan } \\
\text { Fakultas } \\
\text { Pertanian } \\
\text { Fakultas } \\
\text { Peternakan } \\
\text { Fakultas } \\
\text { Teknologi } \\
\text { Pertanian }\end{array}$ & $\begin{array}{l}\text { Fakultas } \\
\text { Ekonomika } \\
\text { dan Bisnis } \\
\text { Fakultas } \\
\text { Ilmu } \\
\text { Budaya } \\
\text { Fakultas } \\
\text { Filsafat } \\
\text { Fakultas } \\
\text { Hukum } \\
\text { Fakultas } \\
\text { ISIPOL } \\
\text { Fakultas } \\
\text { Psikologi }\end{array}$ \\
\hline
\end{tabular}

- Sampel diambil berdasarkan kategori mahasiswa, dosen dan tenaga kependidikan, baik laki-laki dan perempuan.

- Pengolahan data statistik dilakukan secara komputerisasi.

- Hasil penyebaran angket meliputi pemaparan tentang: a. Data responden

b. Intensitas pencarian data di perpustakaan (kunjungan fisik atau virtual)

c. Kecenderungan mahasiswa mengambil sumber referensi untuk karya tulis.

Untuk lebih memudahkan pengisian kuesioner, peneliti membagi tingkatan kunjungan yaitu, selalu untuk kunjungan 5-6 kali dalam seminggu, sering untuk 3-4 kali dalam seminggu, jarang untuk 1-2 kali dalam seminggu. Metode ini memudahkan penelitian untuk mengetahui kecenderungan dalam sebuah populasi dengan menggunakan sampel. Pemilihan sampel dengan metode yang tepat dapat menggambarkan kondisi populasi sesungguhnya yang akurat, dan dapat menghemat biaya penelitian secara efektif. Idealnya, sampel benar-benar menggambarkan atau mewakili karakteristik populasi yang sebenarnya. Karena data yang diperoleh dari sampel harus dapat digunakan untuk menaksir populasi. Sampel yang dapat mewakili populasinya disebut sampel representatif. Sampel representatif memiliki ciri karakteristik yang sama atau relatif sama dengan ciri karakteristik populasinya. Tingkat kerepresentatifan sampel yang diambil dari populasi tertentu sangat tergantung pada jenis sampel yang digunakan, ukuran sampel yang diambil, dan cara pengambilannya.

Salah satu metode yang digunakan untuk menentukan jumlah sampel adalah menggunakan rumus Slovin (Sevilla et.al, 2007;182) sebagai berikut:

$$
n=\frac{N}{1+n e^{2}}
$$

n: Jumlah Sampel $=52.500$

N: Jumlah Populasi $=52.500$

e: Batas Toleransi Kesalahan (error tolerance) $=0,01$

Dari hasil rumus di atas, jumlah civitas akademika di UGM meliputi jumlah mahasiswa dan dosen adalah 52.500 orang. Sehingga jumlah sampel yang didapat adalah 981 orang. Dalam pengambilan sampel menggunakan accidental sampling yaitu pengambilan sampel dengan cara acak.

\section{Rancangan Penelitian}

Penelitian akan dilaksanakan dengan konstruksi sebagai berikut:

1. Sampel dalam ini yaitu civitas akademika meliputi mahasiswa, dosen, dan fungsional khusus. 
2. Tempat penelitian adalah Perpustakaan Universitas Gadjah Mada serta di lingkungan kampus UGM.

3. Pengambilan data dengan menggunakan kuesioner dan dipandu oleh surveyor yang berasal dari tenaga part time Perpustakaan UGM.

4. Kuesioner yang telah diisi sivitas akademika UGM akan dianalisa.

5. Data akan dianalisa untuk mengetahui bagaimana kontribusi perpustakaan sebagai penyedia literatur untuk menyusun karya ilmiah.

6. Peneliti akan menganalisa kecenderungan pemustaka mencari literatur yang disediakan oleh Perpustakaan UGM untuk penulisan karya ilmiah.

7. Data diolah menggunakan program SPSS untuk mendapatkan hasil seperti yang menjadi tujuan penelitian.

8. Hasil penelitian disajikan dalam bentuk diskriptifkuantitatif.

Penelitian akan dijalankan dengan tahapan sebagai berikut:

1. Proses persiapan penelitian dengan mengumpulkan dokumen dasar bahan penelitian

2. Pengumpulan data awal

3. Penyebaran kuesioneer secara proporasional

4. Pengumpulan dan tabulasi data hasil kuesioneer

5. Validasi dan koreksi data terkumpul

6. Menganilisa tujuan penggunaan sumber daya informasi dan jenis sumber informasi yang dibutuhkan,

7. Menganalisa tingkat kepentingan sumber daya informasi, relevansi dan kemutakhiran.

8. Menganalisa kecenderungan litertur yang digunakan dalam pencarian data dan informasi dalam menyusun karya tulis ilmiah

9. Menganalisa tingkat kepuasan penggunaan sumber daya informasi yang tersedia di Perpustakaan UGM.

10.Membuat rekomendasi dan pelaporan penelitian.

\section{HASIL DAN PEMBAHASAN}

1. Data Responden

Dalam penelitian ini responden adalah sivitas akademika UGM yang terdiri dari mahasiswa, para dosen dan tenaga kependidikan. Dari hasil penelitian menunjukan bahwa yang menggunakan perpustakaan dalam menyusun karya tulis ilmiah $98 \%$ pemustaka adalah mahasiswa. Selebihnya dosen $1 \%$ dan $1 \%$ berasal dari tenaga kependidikan.

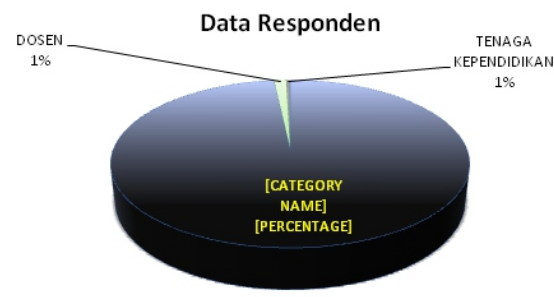

-MAHASISWA ¿DOSEN IIENAGA KEPENDIDIKAN

Gambar 1. Data responden sivitas akademika pengguna perpustakaan UGM

\section{Responden Berdasarkan Klaster}

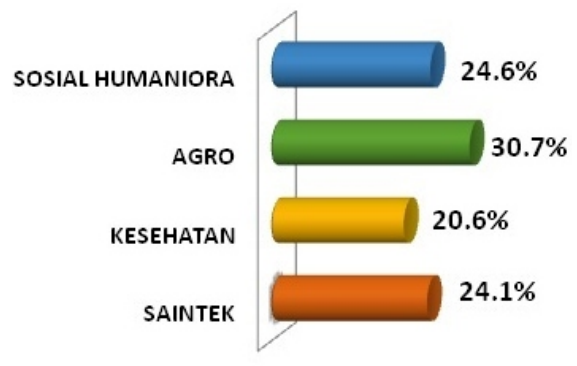

Gambar 2. Responden dari keempat klaster

Dari hasil penelitian menunjukan bahwa mahasiswa UGM terdiri dari 18 Fakultas dan terbagi menjadi empat klaster besar. Keempat klaster adalah pertama, Klaster Sosio Humaniora yang terdiri dari enam fakultas yaitu Fakultas Ekonomika dan Bisnis, Fakultas Ilmu Budaya, Fakultas Filsafat, Fakultas Hukum, Fakultas Ilmu Sosial dan Ilmu Politik dan Fakultas Psikologi.Klaster ini mendapatkan responden sebanyak $24.6 \%$.

Kedua, Klaster Argo terdiri dari lima fakultas yaitu Fakultas Kedokteran Hewan, fakultas Kehutanan, Fakutas pertanian, Fakultas Peternakan, Fakutas Teknologi Pertanian. Klaster ini mendapatkan responden sebanyak $30.7 \%$ 
Ketiga, Klaster Kesehatan. klaster ini terdiri dari tiga fakultas yaitu Fakultas Kedokteran Umum, Fakultas Kedokteran gigi dan Fakultas farmasi. klaster ini mendapatkan responden sebanyak $20.6 \%$.

Keempat, Klaster Saintek. klaster ini terdiri dari empat fakultas yaitu Fakultas Biologi, Fakultas Geografi, dan Fakultas Teknik. klaster ini mendapatkan responden $24.1 \%$.

Persentase responden dari setiap fakultas dapat dilihat pada gambar 3

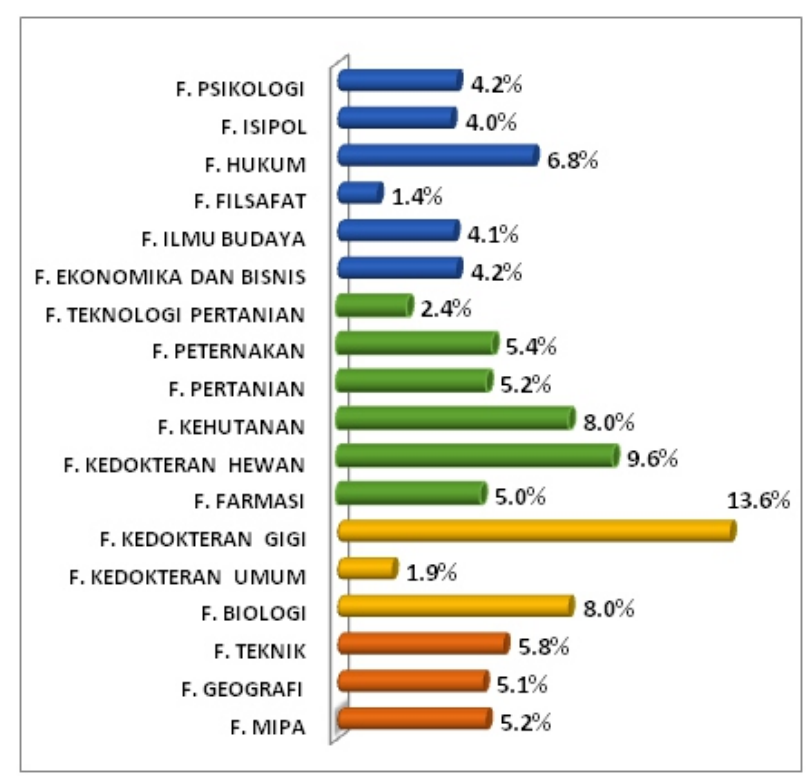

Gambar 3. Pembagian responden berdasarkan tiap fakultas

\section{Intensitas Pencarian Data di Perpustakaan}

Hasil penelitian menunjukkan bahwa pemustaka yang terdiri dari seluruh esivitas akademika sebagian besar mengunjungi perpusatakan baik dalam kunjungan fisik dan virtual sebanyak 53\%. Pemustaka tergolong jarang melakukan kunjungan dengan penjelasan bahwa jarang adalah kunjungan yang hanya dilakukan sekali sampai dua kali dalam satu minggu.

Posisi terbanyak lainnya sivitas akademika melakukan kunjungan ke perpustakaan 3-5 kali dalam satu minggu sebanyak 35\%. Pemustaka ini tergolong sebagai pemustaka cukup mengunjungi perpustakaan.

Selain itu, terdapat jumlah $7 \%$ responden yang tidak pernah sama sekali mengunjungi perpustakaan baik fisik maupun virtual. Sisanya sebanyak 6\% adalah pemustaka yang sering mengunjungi perpustakaan setiap hari dengan kisaran 6-7 hari dalam seminggu.

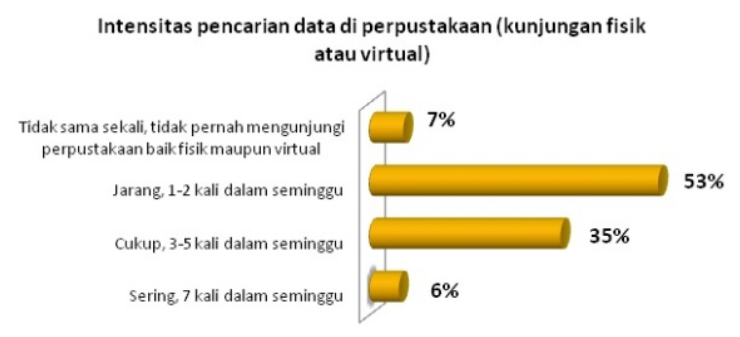

Gambar 5. Data berdasarkan intensitas kunjungan civitas akademika ke perpustakaan UGM baik fisik mapun virtual

\section{Kecenderungan Sivitas Akademika dalam Memilih Sumber referensi Untuk Karya Tulis Ilmiah di Perpustakaan UGM}

Perpustakaan Universitas Gadjah Mada sebagai penyedia sumber referensi untuk karya tulis ilmiah memiliki beberapa sumber informasi dalam bentuk Jurnal Cetak, E-book, Respositiry, Karya Ilmiah dosen, Buku Teks, dan Jurnal Online.

Hasil penelitian menunjukkan bahwa sivitas akademika yang menggunakan perpustakaan sebagai penyedia refeensi lebih banyak menggunakan jurnal online dengan total persentase $22.65 \%$. Selanjutnya disusul oleh Buku Teks dengan besaran $18.00 \%$. selanjutnya E-book sebesar 16.46 $\%$ dan Respository sebesar $16.11 \%$. selanjutnya jurnal cetak sebesar $13.18 \%$ dan Karya ilmiah dosen sebesar $13.60 \%$.

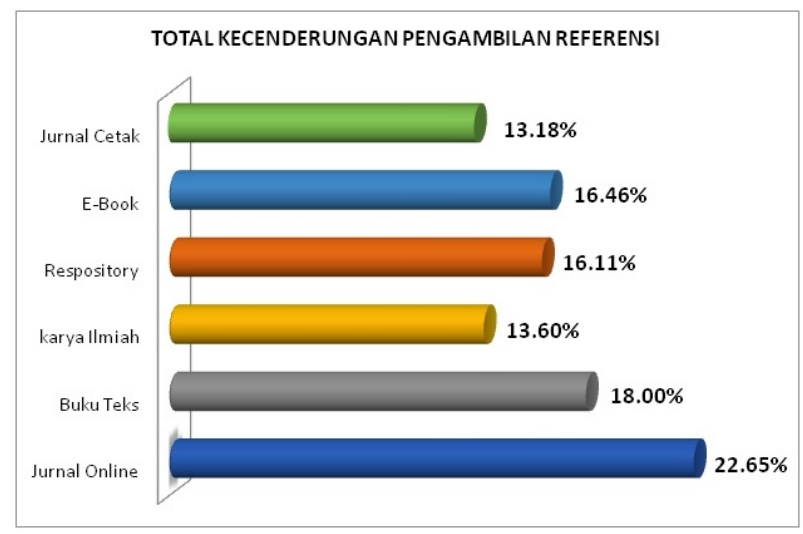

Gambar 6. Data kecenderungan sivitas akademika menggunakan data referensi dalam menyusun karya tulis ilmiah

Secara lebih rinci kecenderungan setiap klaster juga dapat diketahui sumber referensi yang digunakan dalam menyusun karya tulis ilmiah adalah sebagai berikut.

\section{a. Klaster Saintek}

Pada klaster saintek sivitas akademika lebih banyak menggunakan jurnal online untuk mencari sumber referensi dalam menyusun 
karya tulis ilmiah sebanyak $23.15 \%$. selanjutnya $17.53 \%$ memilih E-book dan $16.49 \%$ memilih Respository. Sisanya sivitas akademika menggunakan Buku Teks sebesar 15.46\% dan Jurnal Cetak sebesar 13.30. sedangkan karya tulis ilmiah paling rendah sebesar $14.07 \%$.

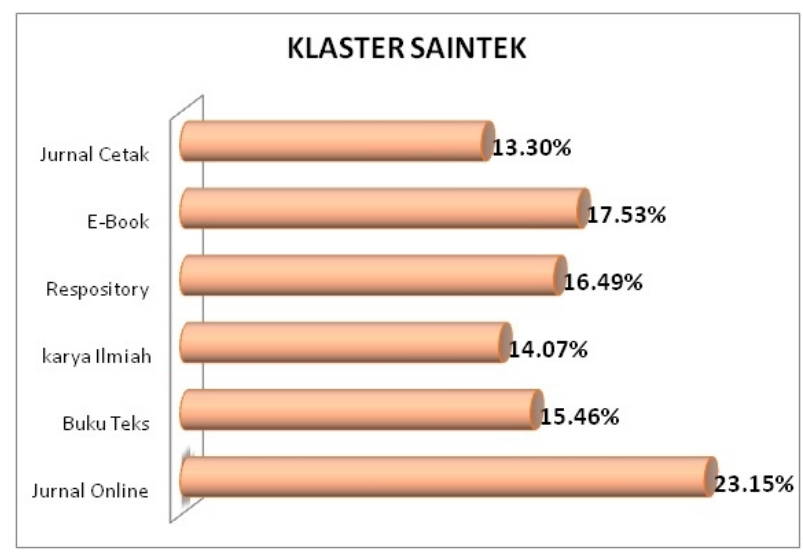

Gambar 8. Civitas akademika Klaster Saintek dalam memilih sumber referensi dalam penyusunan karya tulis ilmiah

\section{b. Klaster Kesehatan}

Sivitas akademika klaster kesehatan dalam mencari sumber referensi saat menyusun karya tulis ilmiah adalah memilih jurnal online sebesar $22.58 \%$ dan Buku Teks 18.06\%. selanjutnya $e$ book $18.01 \%$ dan jurnal teks $12.64 \%$. selebihnya respository $14.43 \%$ dan Karya tulis Ilmiyah dosen $14.29 \%$.

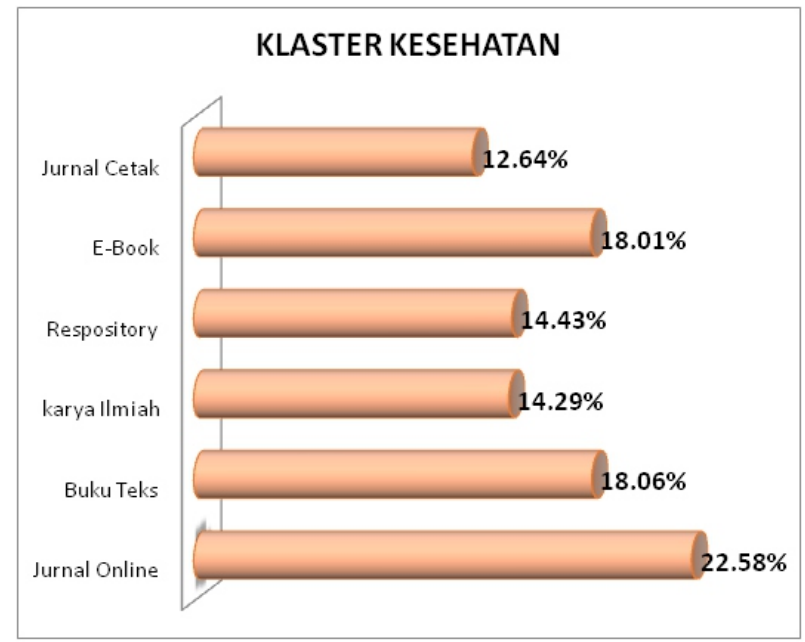

Gambar 9. Kecenderungan Klaster Kesehatan dalam memilih sumber referensi dalam menyususn karya tulis ilmiah

\section{c. Klaster Agro}

Klaster Agro sebagian besar memilih Jurnal online sebesar $22.10 \%$ sebagai prioritas dalam mencari sumber referensi. Selanjutnya respository sebesar $17.41 \%$ dan Buku teks $16.33 \%$. setelah itu sivitas akademika memilih jurnal cetak sebesar $14.75 \%$ dan E-book sebesar $15.62 \%$. sedangkan karya tulis ilmiah dosen sebagai pemilihan terakhir dalam mengambil sumber referensi yaitu $13.79 \%$.

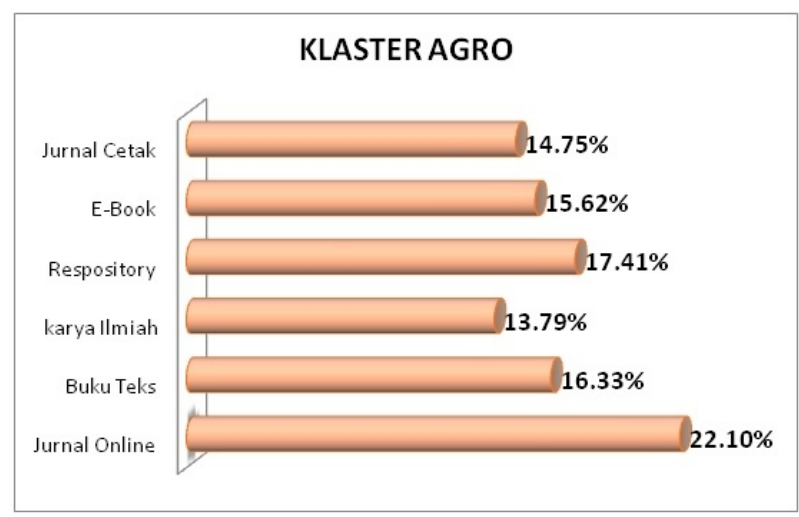

Gambar 10. Kecenderungan Klaster Agro dalam memilih sumber referensi dalam menyusun karya tulis ilmiah

\section{d. Klaster Sosial Humaniora}

Pada klaster sosial humaniora lebih banyak sivitas akademika memberikan prioritas pada Jurnal online sebesar $22.84 \%$ sebagai pencarian sumber referensi. Selanjutanya prioritas lainnya adalah Buku Teks sebesar $22.76 \%$. selebihnya secara berturut turut antara Respository sebesar $15.57 \%$ dan E-book sebesar $15.10 \%$. selebihnya karya tulis ilmiah dosen sebesar $12.31 \%$ dan Jurnal cetak $11.42 \%$.

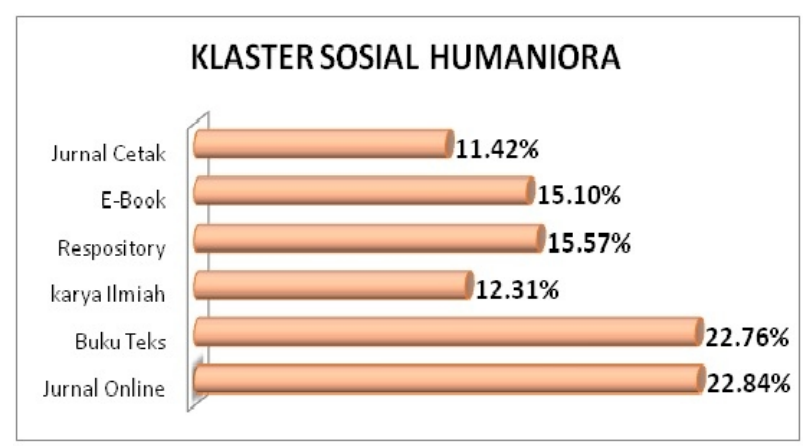

Gambar 11. Kecenderungan Klaster Sosial Humaniora dalam memilih sumber referensi dalam menyususn karya tulis ilmiah

\section{E. KESIMPULAN}

Hasil penelitian ini dapat disimpulkan bahwa:

a. Jumlah responden yang mewakili civitas akademika UGM sebesar 982 orang dan terbagi menjadi mahasiswa sebesar $98 \%$ dan dosen $1 \%$ serta tenaga kependidikan 1\%. Perpustakaan UGM telah berkontribusi menyediakan 
referensi untuk karya tulis ilmiah bagi civitas akademika. Hal ini dilihat dari seluruh hasil penelitian yang menunjukkan bahwa sebagian besar civitas akademika (53\%) melakukan kunjungan ke perpustakaan, dan sebagian besar menggunakan referensi dalam bentuk jurnal online $(22.65 \%)$ untuk menunjang penyusunan karya tulis ilmiah.

b. Intensitas pencarian data di perpustakaan kategori jarang mengunjungi perpusatakaan baik dalam kunjungan fisik dan virtual sebanyak 53\% dengan intensitas kunjungan 1-2 kali dalam seminggu. Kategori cukup melakukan kunjungan ke perpustakaan 3-5 kali dalam satu minggu sebanyak $35 \%$. Selain itu, terdapat jumlah $7 \%$ responden yang tidak pernah sama sekali mengunjungi perpustakaan baik fisik maupun virtual. Sedangkan sisanya sebanyak $6 \%$ adalah pengguna yang sering mengunjungi perpustakaan setiap hari dengan kisaran 6-7 hari dalam seminggu.

c. UGM terbagi menjadi empat klaster besar berdasarkan bidang keilmuan yang berisi fakultas yang sejenis dengan jumlah respondennya yaitu klaster saintek dengan responden $24.1 \%$, klaster Agro sebesar 30.7\%, klaster Kesehatan sebesar $20.6 \%$ dan klaster Sosial Humaniora sebesar 24.6\%

d. Kecenderungan sivitas akademika Universitas Gadjah Mada dalam menggunakan sumber referensi dalam menyusun karya tulis ilmiah memprioritaskan jurnal online sebesar $22.65 \%$, Buku Teks 18.00\%. E-Book sebesar 16.46\%, Repository sebesar $16.11 \%$, Karya Ilmiah dosen sebesar $13.60 \%$ dan Jurnal cetak sebesar $13.18 \%$.

Merujuk pada hasil penelitian ini, peneliti memberikan saran sebagai berikut:

a. Dapat dilakukan penelitian lanjutan mengenai kontribusi perpustakaan secara lebih mendalam dengan pendekatan-deskriptif kualitatif.

b. Merekomendasikan jurnal online untuk dipertahankan atau bahkan ditingkatkan baik dalam skala kualitas dan kuantitas mengingat kebutuhan sivitas akademika yang tinggi.

c. Perlunya sosialisasi sumber-sumber informasi yang ada di Perpustakaan UGM agar pemanfaatan jurnal online lebih banyak dipakai sebagai sumber literatur.

\section{DAFTAR PUSTAKA}

Buku Pedoman KKN-PPM Universitas Gadjah Mada Periode Semester Genap. 2016. Direktorat Pengabdian Kepada Masyarakat UGM. Yogyakarta.

Devito, Joseph A. 1997. Komunikasi Antar Manusia, Jakarta, Profesional Book.

Handayani, Rini. 2007. Analisis Faktor-Faktor yang Mempengaruhi Minat Pemanfaatan Sistem Informasi. SNA X. UNHAS Makasar 26-28 Juli. STIE A tma Bhalti Surakarta.

Hermanto. 2004. Kajian kemutakhiran referensi artikel ilmiah pada beberapa jurnal ilmiah penelitian pertanian. Jurnal Perpustakaan Pertanian, Volume 13, (1): 1-6.

Ishak. 2006. Kebutuhan Informasi Mahsiswa Program Pendidikan Dokter Spesialis (PPDS) FK-UI dalam Pemenuhan Tugas Journal Reading. Pustaha: Jurnal Studi Perpustakaan dan Informasi, Vol 2 No. 2

Kriyantoro, R. 2007. Teknik Praktis Riset Komunikasi. Kencana, Jakarta.

Munir, H.A.S. 2006. Manajemen Pelayanan Umum di Indonesia. Bumi Aksara, Bandung.

Parasuraman, A. Valarie A., Zeithaml, and Leonard L. Berry. A.1985. A Conceptual Model of Service Quality and its Implications for Future Research. Journal of Marketing. Vol 49 (Fall).

P.Sumardji.1991. Perpustakaan Organisasi Dan Tata Kerjanya, Yogyakarta, Kanisius.

Sekaran, Uma. 2007. Metodologi Penelitian untuk Bisnis.Edisi 4.Buku 2. Jakarta: SalembaEmpat.

Septiyantono, T. \& Sidik, U. 2003. Dasar-dasar Ilmu Perpustakaan dan Informasi. Jurusan Ilmu Perpustakaan dan Informasi, Fakultas Adab IAIN Sunan Kalijaga, Yogyakarta.

Suryantini, H. 2004. Pemanfaatan Informasi Teknologi Pertanian oleh Penyuluh Pertanian. Kasus di Kabupaten Bogor, Jawa Barat. Jurnal Perpustakaan Pertanian. Volume 13 (1): 1723.

Sevilla, Consuelo G. et. al (2007). Research Methods. Rex Printing Company. Quezon City 